Journal of Social Sciences 3 (2): 43-51, 2007

ISSN 1549-3652

(C) 2007 Science Publications

\title{
What Characterise the Nordic Welfare State Model
}

\author{
Bent Greve \\ Department of Society and Globalisation, Roskilde University, Denmark
}

\begin{abstract}
This article presents the main distinctive characteristics of the Nordic welfare states. These include, for example, full employment, high degree of equality, a high level of taxes and a high level of public spending on welfare. The article further presents data, which enables the reader to a comparison with welfare states in Europe and to analyse whether we are witnessing convergence in Europe and/or the withering away of the Nordic Model. The conclusion being that the Nordic Model is here to stay, although a movement in a European direction is underway.
\end{abstract}

Keywords: European model, Nordic welfare state model, convergence, full employment, equality

\section{INTRODUCTION}

Describing what characterise the Nordic welfare state model is the core aim of this article. Furthermore, the article will analyse whether the model will continue to be different from other welfare state types. The Nordic welfare states have been, as other welfare states, under pressure from Europeanisation and globalization. These challenges for regional defined, historical developed and managed welfare states could be a reason for converging trends in welfare states. Furthermore, this could be a reason for the development of a more uniform and common European type of welfare states. This due to that it is to be expected, that a common European model would be under less pressure within the European Union and the Economic and Monetary Union as this could adapt to the economic possibilities. Pressure for change may apply in particular in the case of welfare states models with high emphasis on state financing, such as the Nordic welfare state model. A clear focus of this article is a depiction of the specific characteristics of the Nordic welfare state, but done in a comparative perspective and at the same time questioning and discussing convergence in a European perspective. The article uses the comparative methodology as this and models make it possible to have a mirror with which to compare the Nordic model.

The pressure, it has been argued, would make it impossible to maintain a specific national welfare state with a high degree of emphasis on full employment and equality, but it also seems that "despite undeniable problems posed by economic internationalisation, social democratic welfare states and employment regimes have proven to be highly resilient" ${ }^{\text {[1] }}$. Economic internationalisation can be both impact from Europeanisation and Globalisation.

High levels of taxes and high wages do thus not necessarily make welfare regimes with high levels of public intervention uncompetitive with other welfare states, despite the reduction in effectiveness of the traditional Keynesian economic policies. One reason could be differences between the compositions of the export sectors in the different regimes; another could be a higher emphasis on human-capital formation and high labour-force participation in regimes with high levels of public intervention. This does not affect by itself the issue of how to steer and manage the economy in different welfare states. This is due to that the increased economic integration between economies and internationalisation has changed the traditional ability to maintain overall economic policy-making. Thereby has, at least for small countries, the option of using traditional economic steering mechanisms been reduced.

The emphasis in this article is thus on whether, on the basis of ongoing Europeanisation and globalization and its possible impact on the continuation of a national welfare state, one might be able to identify any specific traits in the development of the Nordic welfare states.

The article is divided in several subsections. Firstly, the article will discuss briefly the concepts of the welfare state. Secondly, the article will by way of comparative data try to depict whether certain characteristics are still at hand when looking at the Nordic welfare states. Finally, the article will discuss the tendency, towards convergence of social policies in a European perspective, as convergence could be a reason for the withering away of a specific Nordic welfare state. 
A core thesis to be explored is that Europeanisation and globalisation is not a threat to the development and maintenance of universal Nordic welfare states, but that we are witnessing convergent trends, which might be influenced by these factors. This article will thus also question the conclusions of among others Pierson ${ }^{[2]}$ and Scharpf and Schmidt ${ }^{[3]}$ - who, for example, conclude: "that there is no convergence in the welfare state".

Methodologically, the overall argument on convergence will mainly be pursued via a combination of analysis of concepts and theoretical arguments on welfare state development coupled with empirical support from international comparative economic and social data.

What is a welfare state - and what is the Nordic welfare state model: A core issue in the discussion of the welfare state is how to define it, how to define its boundaries and the connections between the welfare state and other aspects of societal development. Historically, the term was introduced in the 1930's. Yet, a single, commonly agreed definition still does not exist $^{[4]}$. This despite, that already Titmuss in 1962 said: "The term has apparently come to mean all sorts of thing" ${ }^{,[5]}$. It seems, though, that in many ways the debate surrounding the welfare state revolves around the interaction between state, market and civil society. Furthermore, the debate includes how the state deals with essentially democratic decisions on issues such as economic prosperity, employment, housing, health, social security and education and whether the state does this in such a way that at least some minimum standards are achieved.

The core of the Scandinavian or Nordic model, for a long time, has been argued to be "to improve the ability of society to master its problems and to enrich and equalize the living conditions of individuals and families. In social policy, the cornerstone of the model is universalism, ${ }^{,[6]}$. For a further debate on universalism, cf. Kristensen this volume.

Universalism has thus been argued as a central aspect of the Nordic countries and "universal welfare policies are often contrasted with selective policies of a residual, means-testing kind, targeted at the poor, ${ }^{\text {,[7] }}$. An argument for the universal welfare states in the Nordic countries has in fact been that universal programmes are better and less stigmatizing than means-tested benefits and further that they could be a way to ensure consensus and support from the middleclass. Universalism has thus been a point of departure also making it possible for the agrarian and labour movement in agreement to develop the societies ${ }^{[8]}$,

Already Titmuss in 1968 pointed to that
"Universalism is not, by itself alone, enough: in medical care, in wage related social security and in education. This much we have learnt in the past two decade from the facts about inequalities in the distribution of incomes and wealth" ${ }^{\text {"[9] }}$.

Still, the difference in balance between the various elements, which can be part of the scope and task for a welfare state, might even explain why many countries label themselves welfare states, even though with a very different approach to delivery and financing of the activities. Moreover, this might also be a reason why it has been possible, within the European Union to discuss and talk about a European Social Model: because the expression can be interpreted with different meanings and connotations.

Whatever has been labelled a welfare state it has been under pressure over the last 20-25 years. Pressures on the welfare state have been grouped under the following three headings:

* Difficulties in financing due to globalisation and changed technology

* A changed context of welfare policy-making, including the growing importance of the EU-level

* Change in the overall level of demand for welfare, due to demography, family patterns and the labour market ${ }^{[10]}$.

Especially the first heading (financing) has it been argued have an impact on the Nordic welfare states development. The argument being that developments in the free movement of capital and labour imply that the possibilities for national variations in financing have been reduced. This implies that high-level spending welfare states needing state financing of welfare have more difficulties now and in the future to find the necessary means to achieve the goals of the welfare states.

The two other types of pressures do also have an impact, especially if linked to the argument on financing. Change at the supranational level (EU) and change in demography have in various ways an impact on the level and the manner in which also the Nordic welfare states are structured. Demography does so because of the need for expenditure to fulfil the minimum needs arising from more elderly who need health care, pensions and other types of care, while there are fewer on the labour market.

The ageing of societies had or might in the future have an impact, creating a pressure on the welfare state due to the changed demographic composition also in the Nordic countries. On the EU (EU-15) level, it is expected that up to the year 2050 demographic changes imply the following increases in central areas of public sector spending (figures are percentages of GDP): 
Public pension expenditure

3.2

Health Care

$1.3-1.7$

Long-term Care

$0.9-1.0$

There are huge variations between the member states, but in any case, these figures indicate not necessarily budgetary challenges, but rather a conflict and a distributional issue to be solved in most welfare states $^{[11]}$. This naturally could imply a debate on the balance between different sectors in society and if the economic room for manoeuvre is small, then changes will be difficult. The degree of pressure on public sector spending depends to a high degree on the success of the labour-market policies and the ability to increase the participation rate and the average age of retirement from the labour market. If the presently expected increases in participation rate and age of retirement are successfully achieved, then the pressure on public sector spending will be less. All the same, transitional problems will arise, as will a need to transfer economic resources from one area of public spending to another. Arguments of the consequences of demographic transitions can be used as a starting point for changes in the universal Nordic welfare states.

In the welfare state literature different key words have been attached to the Nordic model when analysing welfare regimes. In an overview of typologies of regimes, the following has been presented ${ }^{[12]}$ :

Esping-Andersen (1990) social-democratic: High level of decommodification; universal benefits and high degree of benefit equality

Leibfried (1992) Scandinavian (modern): Right to work for everyone; universalism, welfare state as employer of first resort and compensator of last resort

Castles and Mitchell (1993) non-right hegemony: High social expenditure and use of highly equalising instruments in social policy

Siaroff (1994) protestant social-democratic: True work-welfare choice for women; high level of family benefits and always paid to the mother; importance of Protestantism

Ferrera (1996) Scandinavian: social protection as citizenship right; universal coverage; relatively generous fixed benefits for various social risks; financing mainly through fiscal revenues; strong organizational integration

Bonoli (1997) Nordic: Low percentage of social expenditure financed through contributions (Beveridge); high social expenditure as a percentage of GDP

Korpi and Palme (1998) encompassing: Entitlement based on citizenship and labour force participation; use of flat-rate and earnings related benefit principle

With a few exceptions, the Nordic countries are placed in the above groups. Finland is an exception in Esping-Andersen where it is placed in the Conservative group. Denmark is an exception in Korpi and Palme where it is placed in the basic security model.

Greve $^{[13]}$ focus on that in the Nordic welfare state, in what he has labelled the Scandinavian, Socialdemocratic, Keynesian model, the state is the main responsible for organising and financing the welfare state.

If we were to describe, based upon the above typologies what broadly could be accepted, as distinctive to the Nordic model it would be the following features:

Extremely decentralised and at the same time complex structure regarding both regulations as well as financing; High degree of equality; Active labour market policy with high level of employment (also for women) and low level of wage differentiation; High level of taxes; Family friendly in the sense that the public sector has been actively involved in delivery of day care for children, leaves schemes for parents and a high level compared to other welfare states of economic support for families with children.

The Nordic welfare states have further also been described as service welfare states. This especially due to service delivery with regard to delivery of social care (children and elderly) and health care service by the public sector. Especially family policy has been high on the agenda in the Nordic countries ${ }^{[14]}$. Finally, the consensual approach on how to develop social policy in the Nordic countries can be mentioned.

These distinctive characteristics of the Nordic model are used when choosing data for the analysis. Whether these features still prevail will be analysed by looking at data for specific core elements such as employment/unemployment, degree of equality, poverty and social exclusion, spending on welfare, and how rich the Nordic countries are in comparison with other EU-countries.

Delivery as a central issue in the Nordic welfare states: Arguments for public sector intervention, for example due to market failure (which has been the historical reason for intervention) do not per se give any indication of which type of intervention is needed. 
What can be agreed upon to be the best instrument to use in intervention will vary, depending on specific national and historical developments and on the more specific goals, the welfare state wants to achieve by the intervention. Reasons for intervention still exist and even with the development of more global needs for sufficient information, the reduction of other risks and uncertainty without doubt remain an issue for a welfare state $^{[15]}$.

However, intervention can and does take different forms in different welfare states and approaches have changed in most countries over the last 15-20 years. It is possible to distinguish between several forms of intervention: ranging from very direct intervention in the allocation of resources, to indirect corrections, for example, through the use of the legal system. The boundaries between the state, the market and civil society can thus be changed through various channels of intervention. In its most direct form, intervention transfers delivery from the private sector or takes it over from civil society. In the Nordic universal welfare states, financing and delivery are often by the state, including in the area of services. This in contrast to the more liberal types of welfare state using market delivery to a higher degree - although there will also be state economic support to ensure a decent living standard for the most vulnerable.

Table 1 accordingly shows the types of the interventions one could expect to find in a Nordic type of welfare states. The emphasis is on the consequences of intervention. In the Nordic welfare states, the main type of delivery used has been the direct approach, although recent years have seen tendencies towards the use of other approaches including more market and use of private elements in the delivery of welfare ${ }^{[16]}$.

Different kinds of intervention can also be found in Barr $^{[17]}$, who distinguishes between types of allocation and how they are related to production, regulation and financing. Barr's account then indicates all the varieties from what is labelled "pure public" too "pure private". Such an account also clearly indicates the possibility of moving gradually from public sector provision (financing and decisions on consumption made for the individual as in the traditional areas of the state: defence, police, administration etc.) to the fully marketbased areas of traditional goods, such as, food consumption.

Instead of pursuing the aims and consequences of intervention, a distinction can be made between provisions and financing, as is shown in Table 2 (inspired by ${ }^{[18]}$ ). Here the discussion revolves more around how different kinds and combinations of production/financing and provision can be achieved.

Table indicates that financing and provision can be, but do not need to be, linked to each other. Yet, this distinction, at least implicitly, build upon Titmuss division between public, fiscal and occupational welfare. At the same time, this Table implies a role for the various elements in the welfare state triangle, i.e. between state, market and civil society. Finally, the Table indicates a very broad variety of possible ways of delivery of welfare state services. No normative presuppositions are implied in the Table, as no consequences for equity are attached to it. The Nordic countries have often both financing and delivery inside the public sector, e.g. placed in the upper left corner of the Table.

A reduction of the state's impact and influence on social policy also being witnessed in the universal Nordic welfare states, implies that a new avenue is opening up for the developments. There is therefore a need for steering mechanisms, which can ensure that, on the one hand, the benefits of more open economies are guaranteed and on the other hand, these benefits are distributed to all members of a society. This can happen either in a context of corporate social responsibility or by having at least a minimum income protection available in a society.

It is useful, as indicated by the two Tables, to be aware of the fact that reasons for public sector intervention with the aim of improving society's welfare does not imply in itself public sector production. Rather it clarifies the need to find out what is needed in order to find out the specific requirement for which any given type of intervention is the best. Financing and delivery thus do not have to be fully intertwined and the relationship between them may be an area where a change in the welfare state can be witnessed.

Is the convergence of welfare states a reason for their survival? This section will deal with whether or not we are witnessing convergence among mainly EU countries focussing on the Nordic model. This is based on the assumption that supra-regional convergence can take place. Specifically the analysis will also focus on social exclusion comparing the Nordic welfare model with other welfare models in Europe, using a clustering of countries as the methodological device. After a short introduction, the section will discuss the concept of convergence and will then analyse, by using the coefficient of variation as the main indicator, the development towards convergence, but also if the distinctness of the Nordic model still prevail. 
Table 1: Interventions in the Nordic universal welfare states

\begin{tabular}{lll}
\hline Type of intervention & Possible actions & Consequences \\
\hline $\begin{array}{l}\text { Direct } \\
\text { Indirect }\end{array}$ & $\begin{array}{l}\text { Delivery of services } \\
\text { Benefits in cash, as vouchers or in other forms }\end{array}$ & $\begin{array}{l}\text { Access following publicly decided criteria - often universal } \\
\text { Individuals can decide how to achieve services/goods - extension } \\
\text { of free-choice an example. Risk of negative welfare consequences }\end{array}$ \\
Indirect & $\begin{array}{l}\text { Voluntary support, perhaps financial or obligatory by } \\
\text { Building social partnerships, incentives for action }\end{array}$ \\
& Moral appeal & $\begin{array}{l}\text { Individual action towards other citizens/Companies social } \\
\text { responsibility }\end{array}$ \\
\hline
\end{tabular}

Table 2: The distinction between financing and provision

\begin{tabular}{llll}
\hline Production\Financing & Public Sector & Private Organisations & Private - informal \\
\hline Public & Direct delivery through public institutions & $\begin{array}{l}\text { Profit/Non-profit based upon Families, self-help groups, which } \\
\text { support to delivery certain services might be supported }\end{array}$ \\
Private & User charges, vouchers, obligatory insurance & $\begin{array}{l}\text { Companies or individual based Between relatives, friends } \\
\text { upon certain criteria pays }\end{array}$ \\
\hline
\end{tabular}

Table 3: Number of times the highest spend more in purchasing power parities per capita in EURO in EU member states than do the lowest, in various years since 1980 (EU 15 countries)

\begin{tabular}{llllllll}
\hline & 1980 & 1990 & 1993 & 1995 & 1996 & 1999 & 2003 \\
\hline Highest/Lowest & 5.4 & 3.7 & 3.4 & 3.3 & 3.3 & 2.5 & 2.7 \\
\hline
\end{tabular}

Source: Calculations based upon Eurostat: Social Protection in EU-member states. Bruxelles, Eurostat, various years.

Table 4: Ranking on the Nordic countries compared to OECD/EU on central parameters

\begin{tabular}{lccrr}
\hline & Denmark & Finland & Norway & Sweden \\
\hline Life Expectancy, 2003 & 24 & 15 & 9 & 6 \\
Public Social Expenditure, 2001 & 2 & 7 & 11 & 1 \\
Total Tax-Revenue, 2003 & 2 & 4 & 5 & 1 \\
National Income pr. capita, 2003 & 7 & 16 & 3 & 11 \\
Unemployment, average 1995-2004 & 9 & 26 & 4 & 17 \\
Employment rate, 2004 & 3 & 14 & 4 & 5 \\
Tertiary Attainment level 25-64, 2003 & 6 & 5 & 8 & 4 \\
Spending on active labour market policy, 2004 & 1 & 5 & 11 & 3 \\
Spending on passive labour market policy, 2004 & 1 & 23 & 17 & 9 \\
Gender pay gap, 2004 & 19 & 4 &.. & 19 \\
Gini-coefficient & 3 & & 2 \\
\hline
\end{tabular}

Source: OECD Factbook, 2006 (first 7 rows), Eurostat web database rest

Note: First 7 rows based upon OECD data ranks 30 countries. Eurostat ranks 24 (EU -25 minus Cyprus, Malta, Poland, Slovenia + Bulgaria, Romania and Norway). For Gender pay-gap it is all EU-25 + Bulgaria, Romania and Norway).

Before approaching this analysis there is a need for a few words about what can be understood by convergence. Wilensky ${ }^{[19]}$ was an advocate for that the convergence of welfare states could be explained as a natural part of the economic development. This viewpoint has been criticised from the power-resource and politics matter approaches, by for example Castles, Stephens and Korpi. Working class or religious parties' strength, agrarian opinion (and its collaboration with the working class) etc., rather than just economic determinism, contribute to understanding the development of welfare states.

The convergence discussion has also involved a discussion about whether it would be a race to the bottom or towards catching-up. Catching-up has mainly been postulated by economic theory and by the claim that economic convergence will have a spillover effect on social policy ${ }^{[20]}$. Spillover can presumably also arise due to learning effects and to the spread of best practice strategies, indicating at least two sets of arguments for moving in a convergent direction.

Finally, convergence has also been attached to the debate on the crisis of the welfare state ${ }^{[21]}$, especially in relation to the question of whether the public sector implies a crowding-out of private initiatives. The rhetoric of crisis of the welfare state and its explanation, are to a high degree attached to the supposed harmonization and convergence, but also to anticipated difficulties in the financing and development of welfare states. This is a conception built partly on a belief that the market is more efficient than the public sector and partly on a disbelief in the ability to redistribute income and wealth continuously.

The same lines of discussion and differences of view can be witnessed in the discussion on Europeanisation and globalisation today. As argued above, one such set of arguments is that open economies contribute to convergence through a race to 
the bottom in order to cope with wage- and taxcompetition from other countries. This claim is built to a high degree on logical deduction ${ }^{[22]}$, rather than on empirical data. A quite different claim, which will be the argument here, is that it is possible to maintain different types of welfare states despite the pressures on the welfare states.

My argument is that although many of the factors discussed earlier (financing, demography etc) are at play and these factors then could imply a more common development of welfare states along converging lines depicted as spending on social security as a percentage of GDP. But, at the same time institutional differences and ways to deliver welfare can be different.

A criticism of using the percentage of spending on social security in relation to GDP has been that this measure does not reflect: Institutional structures, ways of financing, fiscal/occupational welfare, the absolute level of spending, the degree of redistribution and efficiency in delivery and finally the proportion of direct service provision versus cash expenditure. Still, using data on spending inform us on differences and similarities between the welfare states and this is the reason also for doing it here.

Below will be presented data enabling an analysis of whether we are witnessing a convergence among welfare states. In this article, convergence is mainly expected due too the hypothesis of catching up in combination with learning from best practice in other countries.

It seems that EU member states have been moving towards a more uniform level of public sector spending, cf. appendix 1. The variation between the EU-member states has been declining and this indicates that they are moving in the same direction. Thus, we have not seen a race to the bottom, as the social dumping argument anticipated and this indicates that traditional theories of factor equivalence have not proven valid ${ }^{[22]}$. A further reason therefore is that in a Europe with a diversified labour market and economic structures, it is logical to have a variety of institutional settings and therefore not a race to the bottom either in labour regulations or in social security policies is needed.

Relative spending might be misleading if taken alone. Therefore, Table 3 shows the distance between the highest and lowest social spending levels, measured in EURO per capita purchasing power parities in various years. This distance has been halved since 1980, when it was more than five times bigger in the highest spending country than in the lowest. In 2003, the highest spender was Luxembourg (10905) and the lowest could be found in Portugal (4076) among those 15 countries with data since 1980 . In 2003, the lowest level for all member states was Latvia (1174).

Part of this change can be explained by the fact that welfare state services are a luxury good and when societies become richer, they have been more willing to finance a welfare state. Social security has thus not been used as the main instrument to gain or increase competitiveness by comparison with other countries and conversely, European countries in general have not, as was feared, been forced to use the low-wage strategy and a reduction of the welfare state as part of the internationalization of their economies. Alber and Standing ${ }^{[23]}$ conclude that neither convergence nor polarization can be witnessed.

Tendencies to convergence can also be found in the level of total taxation, in the use of indirect taxation and in the proportions paid by the various groups (employers, employees) ${ }^{[20]}$. As might be expected, international economic pressures imply that it is more difficult to have a high level of public sector deficit and over last 30 years there has thus also been a convergence in the levels of that ${ }^{[24]}$.

These factors - income level and taxation - might be part of the explanation of why we are also witnessing convergence in other areas: as countries, economic development seems to be the same, which then also makes it possible for them to catch up and spend more on social policy.

Convergence can be witnessed in other areas than just spending, taxation and income differences. Child mortality and educational enrolment among the 16years-olds has also been converging ${ }^{[25]}$. At the same time however, other indicators (household worklessness, youth unemployment and child poverty) are diverging. Tendencies towards convergence can also be witnessed in the delivery of health care service $^{[26]}$

A further convergence of the level of spending ${ }^{[27]}$ can be found if one includes taxation of benefits and information about certain elements of occupational welfare. Further integrating these aspects, we can also see a levelling-out of spending. In 2001, the data are the following: Austria (24.1), Belgium (25.7), Denmark (25.7), Finland (21.8), France (29.2), Germany (29.2), Ireland (13.6), Italy (25.4), Netherlands (20.9), Spain (18.6), Sweden (28.3) and UK (23.6) ${ }^{[28]}$.

Therefore, it might be that on the level of rhetoric, things look alike at the surface, but when it comes to detailed analysis a more varied and broad picture emerges. Part of this debate concerns whether or not convergent trends can be witnessed and will continue. In addition, as this section has indicated, convergence under several indicators might well go hand in hand with continued differences in some areas and in 
Annex 1: Current expenditure on social protection in \% of GDP for EU 15 countries

\begin{tabular}{|c|c|c|c|c|c|c|c|}
\hline & 1980 & 1990 & 1995 & 1998 & 2001 & 2003 & Change 1990-2003 \\
\hline Austria & & 26,7 & 29,7 & 28,4 & 28,4 & 29,5 & 2,8 \\
\hline Belgium & 28 & 26,8 & 29,7 & 27,5 & 27,5 & 29,7 & 2,9 \\
\hline Denmark & 28,7 & 30,3 & 34,3 & 30 & 29,5 & 30,9 & 0,6 \\
\hline Germany & 28,8 & 25,4 & 29,4 & 29,3 & 29,8 & 30,2 & 4,8 \\
\hline Greece & 9,7 & 22,6 & 20,7 & 24,5 & 27,1 & 26,3 & 3,7 \\
\hline Spain & 18,2 & 20,4 & 21,9 & 21,6 & 20,1 & 19,7 & $-0,7$ \\
\hline France & 25,4 & 27,7 & 30,6 & 30,5 & 30 & 30,9 & 3,2 \\
\hline Ireland & 20,6 & 19,1 & 19,9 & 16,1 & 15,3 & 16,5 & $-2,6$ \\
\hline Italy & 19,4 & 24,1 & 24,6 & 25,2 & 25,6 & 26,4 & 2,3 \\
\hline Luxembourg & 26,5 & 23,5 & 25,3 & 24,1 & 21,2 & 23,8 & 0,3 \\
\hline Netherlands & 30,1 & 32,5 & 31,6 & 28,5 & 27,6 & 28,1 & $-4,4$ \\
\hline Portugal & 12,9 & 15,5 & 20,7 & 23,4 & 23,9 & 24,3 & 8,8 \\
\hline Finland & & 25,5 & 32,8 & 27,2 & 25,8 & 26,9 & 1,4 \\
\hline Sweden & & 32,9 & 35,6 & 33,3 & 31,3 & 33,5 & 0,6 \\
\hline United Kingdom & 21,5 & 23,1 & 28 & 26,8 & 27,2 & 26,7 & 3,6 \\
\hline EU-12/15 & 24,3 & 25,4 & 28,4 & 28,4 & 27,5 & 28,3 & 2,9 \\
\hline Standarddeviation & 6,60 & 4,77 & 5,17 & 4,18 & 4,32 & 4,47 & \\
\hline Arithemetic average & 22,48 & 25,07 & 27,65 & 26,43 & 26,02 & 26,89 & \\
\hline Coefficient of variation & 0,29 & 0,19 & 0,19 & 0,16 & 0,17 & 0,17 & \\
\hline
\end{tabular}

Source. Eurostat various years statistics in focus and also available www.ep.eurostat.ec.europa.eu

Annex 2: Clustering countries with regard to central variables for social exclusion and social protection in 2003

\begin{tabular}{|c|c|c|c|c|c|c|c|c|}
\hline & 1 & 2 & 3 & 4 & 5 & 6 & 7 & 8 \\
\hline EU-25 & 28 & 16 & 12,3 & 18 & 30 & 0,9 & 2,3 & 9,6 \\
\hline Nordic & 30,4 & 10,7 & 11,2 & 16,0 & 24,0 & 1,3 & 0,5 & 5,9 \\
\hline Central & 28,7 & 13,5 & 11,8 & 13,7 & 26,8 & 0,9 & 1,5 & 8,3 \\
\hline Eastern Europe & 21,7 & 15,8 & 9,4 & 10,0 & 27,6 & 0,7 & 3,6 & 9,7 \\
\hline Baltic & 13,5 & 16,3 & 6,4 & 14,3 & 33,0 & 0,3 & 3,0 & 7,0 \\
\hline Southern Europe & 21,7 & 18,0 & 10,7 & 29,2 & 32,0 & 0,6 & 1,5 & 7,6 \\
\hline Atlantic & 21,6 & 19,5 & 7,7 & 32,0 & 33,0 & 1,3 & 0,5 & 14,3 \\
\hline \multicolumn{9}{|c|}{ 1. Social Protection public spending as percentages of GDP in 2003} \\
\hline \multicolumn{9}{|c|}{ 2. At risk of poverty 2003} \\
\hline \multicolumn{9}{|c|}{ 3. Pension expenditures as percentage of GDP in 2003} \\
\hline \multicolumn{9}{|c|}{ 4. At risk of poverty people above 65} \\
\hline \multicolumn{9}{|c|}{ 5. Gini-coefficient } \\
\hline \multicolumn{9}{|c|}{ 6. Expenditure on social exclusion in 2003 as percentages of GDP } \\
\hline \multicolumn{9}{|c|}{ 7. Very-long term unemployment-rate in 2004 as percentage of the labour force, e.g. after more than 24 months of unemployment } \\
\hline \multicolumn{9}{|c|}{ 8. Children living in jobless housholds. 2005} \\
\hline \multicolumn{9}{|c|}{ Source: European Commission, 2006 and own calculations based hereupon } \\
\hline \multicolumn{9}{|c|}{ Note: $\quad$ n } \\
\hline Nordic & \multicolumn{8}{|c|}{ Denmark, Finland and Sweden } \\
\hline Central & \multicolumn{8}{|c|}{ Germany, Austria, France, Belgium, Netherlands, Luxembourg } \\
\hline Eastern Europe & \multicolumn{8}{|c|}{ Czech, Poland, Hungary, Slovak, Slovenia } \\
\hline Baltic & \multicolumn{8}{|c|}{ Estonia, Latvia, Lithuania } \\
\hline Southern Europe & \multicolumn{8}{|c|}{ Greece, Italy, Spain, Portugal, Cyprus, Malta } \\
\hline Atlantic & \multicolumn{8}{|c|}{ Eire, United Kingdom } \\
\hline
\end{tabular}

institutional structures and specific programmes.

Looking at the development using cluster analysis in Appendix 2, some central data on social exclusion and social protection are provided for six clusters. The next section will be looking upon individual Nordic countries positions. These clusters have mainly been chosen geographically, but they also reflect traditional welfare-state analysis ${ }^{[13]}$. Eastern Europe is treated as a single bloc due to its recent transition, with the Baltic States being seen as one group, as they have the lowest levels of spending on social protection.

The appendix shows that in general the Nordic model perform well compared to the other clusters in Europe with risk of poverty for those above the age of 65 at the main exception. However, one thing being the cluster another how individual countries carry out compared to other countries, this can be seen in Section 5.

The Nordic welfare states compared: As mentioned earlier core characteristics of the Nordic welfare states has been their ambition to maintain full employment, a high degree of public welfare and a commitment to equality in a mainly universal delivery of goods and 
services. In order to analyse whether this is still the case in Table 4 the Nordic countries are compared to $\mathrm{OECD} / \mathrm{EU}$ countries on central parameters.

In Table 4, the Nordic countries are ranked on 11 parameters in order to analyse when comparing with the rest of the OECD or EU area the Nordic countries can still be depicted as having a specific place in the categories of welfare states.

The data in Table 4 shows a blurred picture with regard to whether the Nordic countries still are fulfilling the criteria. A criterion could be that the Nordic countries all are in the best $1 / 3$ of the countries (10 for OECD and 8-9 for EU). Using this as a structuring device the Nordic countries position can be split into fulfilling/not fulfilling and some ambiguous:

Fulfilling: tax-revenue, tertiary attainment level, spending on active labour market policy, Ginicoefficient

Not fulfilling: life-expectancy, national income pr. capita, unemployment, gender-pay gab

Ambiguous: public social expenditure and spending on passive labour market policy (only Norway is just outside as number 11), employment rate (only Norway outside as number 14 and the other three countries placed 3, 4 and 5).

More simple put fulfilling in four areas, not fulfilling in other four areas and within the borderlines for the EU countries in three areas with Norway outside the ranking.

Therefore, in a sense the Nordic welfare states are still with a high commitment to have a high employment rate, high labour force participation and an active labour market policy. It is still also countries with a high degree of equality, public sector spending and tax-level.

At the same time, unemployment is high in Sweden and Finland although declining in recent years. It is countries with lower life-expectancy than most other OECD countries (especially Denmark) and countries with a higher gender-pay gap than in other countries. The higher gender pay gap can at least partly be explained by a higher female participation rate and this especially in the public sectors welfare areas where income is lower than in the private sector.

The full picture is thus blurred when it comes to distinguishing the Nordic welfare states from others. Service provision has also been argued to be a cornerstone of the Nordic welfare states, but with the increasing focus on how to combine work and family life, as also becoming part of the European Employment Strategy, day care for children has been on the agenda in many European countries and in this way, the difference might be withering away.

\section{CONCLUSION}

Nordic Welfare States and the Nordic model are here to stay, as the data shows still distinctive elements are clear in the Nordic countries. A core reason is, as discussed in the article, the broad meaning and interpretation of what a welfare state is. This implies that even if many changes take place, and delivery and financing change dramatically in many countries, we would still need a welfare state in order to cope with failure of the market. Furthermore, all welfare states will need to balance the benefits and costs of every activity and it might be that global development will make it more difficult in some areas than in others to maintain the historical basis of the welfare state.

The Nordic welfare states do well when it comes to ensure a high degree of equality and with regard to access to the labour market and public delivery and financing of welfare state activities. Nevertheless, on other areas such as life-expectancy and national income pr. capita they do less well. This reflects also that typologies are mainly a structuring device, which does not necessarily will be followed in each detail in all countries.

I agree further with Barr on globalization and the welfare state when he observes, "the implications for the welfare state are not necessarily apocalyptic" ${ }^{[15]}$. He offers four arguments why this is the case - the main reason being adaptations by the welfare states, both in the already industrialised countries and in the newly industrialised countries.

Perhaps more important is the argument that a change in public consumption does not necessarily change the overall spending level, which could be taken over by employers (e.g. occupational welfare in Titmuss's understanding) and this could be combined with tax-deductions (fiscal welfare). In this sense, the central emphasis on state delivery can be reduced, but, as indicated by the figures and discussion in the article, this does not imply that other ways of delivery and financing cannot take the state's place.

We will thus be witnessing adaptation and changed boundaries between state and market. However, at the same time citizens in the richer welfare states will continue to expect and demand (due to rising income) the delivery of services to cope with needs for care, income-smoothing over the lifetime and our constant requirements for new kinds of consumption. It might be that it is not economic reasons, which bring the servicewelfare state to an end, but more the difficulty of finding the labour willing and prepared to do the job.

The pathways witnessed seems to imply that we see and presumably will continue to see convergence in 
the overall level of spending, economic prosperity, the demographic situation and labour market affiliation; but at the same this leaves every country with room for national decisions reflecting differences in taste, culture and history.

The Nordic countries are thus neither witnessing a race to the bottom, nor a fully-fledged, convergent, integrated development towards a common welfarestate type. At the same time it is the case, as Atkinson has put it, that rolling back the welfare state would "hit hard some of the most disadvantaged members of our societies" ${ }^{29]}$. This might be another reason for that we seem to be witnessing: a continuation of welfare state development.

\section{REFERENCES}

1. Huber, E. J.D. and Stephens, 2002. Globalisation, Competitiveness and the Social Democratic Model. Social Policy and Society, 1: 47-57.

2. Pierson, P. (Ed.), 2001: The New Politics of the Welfare State. Oxford, Oxford University Press.

3. Scharpf, F. and V. Schmidt (Eds.), 2000. Welfare and Work in the Open Economy, Volume II, Oxford, Oxford University Press.

4. Greve, B., 2005. Historical Dictionary of the Welfare State. Lanham and London, Scarecrow Press.

5. Quoted in Alcock, et al. 2001. Welfare and wellbeing. Richard Titmuss contribution to social policy.

6. Erikson, R. et al. (Eds.), 1987. The Scandinavian Model: Welfare States and Welfare Research, New York: $\quad$ M.E. Sharpe

7. Kunhle, S and N. Kildal (Eds.), 2005. Normative Foundations of the Welfare State. The Nordic Experience. London: Routledge.

8. Baldwin, P., 1990. The Politics of Social Solidarity. New York, Cambridge University Press.

9. Titmuss, R.M., 1968. Commitment to welfare. London: Allen \& Unwin.

10. Taylor-Gooby, P. (Ed.), 2001. Welfare States under Pressure. London, Sage.

11. Greve, B. Ed., 2006. The Future of the Welfare State. Aldershof, Ashgate.

12. Table 1 from Arts, Will and Gelissen, John (2002): Three worlds of welfare capitalism or more? A state-of-the-art-report. J. Eur. Social Policy, 12: 137-158.
13. Greve, B., 2002. Vouchers. Nye styrings- og leveringsmåder i velfærdsstaten. København, Djøfs Forlag.

14. Abrahamson, P., T. Boje and B. Greve, 2005. Welfare and Families in Europe. Aldershot, Ashgate.

15. Barr, N., 2001. The Welfare State as Piggy Bank. Oxford, Oxford University Press.

16. Blomqvist, P., 2004. Privatization of Swedish Welfare Services. Social Policy \& Administration, 38: 139-155.

17. Barr, N., 1998. The Economics of the Welfare State. Oxford, Oxford University Press.

18. Glennerster, H., 1992. Paying for Welfare. 1990's. Hemel Hempstead, Harvester Wheatsheaf.

19. Wilensky, H., 1975. The Welfare State and Equality. Berkeley, CA: University of California Press.

20. Kautto, M. et al. (Eds.), 2001. Nordic Welfare States in the European Context.

21. Pierson, C., 1991. Beyond the Welfare State? Cambridge, Polity Press.

22. Adnett, N., 2001. Modernizing the European Social Model: Developing the guidelines. J. Common Market Studies, 39: 353-364.

23. Alber, J. and G. Standing, 2000. Social dumping, catch-up, or convergence? Europe in a comparative global context. J. Eur. Social Policy, 10: 99-120.

24. Ganghof, S., 2000. Adjusting National Tax Policdy to Economic Internationalisation Strategies and Outcomes in Scharf and Schmidt (Eds.), 2000.

25. Mickelwright, J. and K. Stewart, 1999. Is the WellBeing of Children Converging in the European Union. Paper for Conference in Luxembourg. Luxembourg Income Study, Sep. 30-Oct. 2.

26. Freemann, R., 1999. Health Policy and Politics in Europe. In Clasen, Jochen (Ed.).

27. Greve, B., 1996. Indications of Social Policy Convergence in Europe. Social Policy and Administration, 30: 348-367.

28. Adema, W. and M. Ladique, 2005. Net Social Expenditure, 2005 Edition. More comprehensives measures of social support. Social, Employment and Migration Working Papers No. 29. Paris, OECD.

29. Atkinson, A., 1999. The Economic Consequences of Rolling Back the Welfare State. Cambridge, MIT Press. 